\title{
Impacts of salvage-logging on the status of deadwood after windthrow in Swiss forests
}

\section{Journal Article}

Author(s):

Priewasser, Kathrin; Brang, Peter; Bachofen, Hansheinrich; Bugmann, Harald; Wohlgemuth, Thomas

Publication date:

2013-03

Permanent link:

https://doi.org/10.3929/ethz-b-000065158

Rights / license:

In Copyright - Non-Commercial Use Permitted

Originally published in:

European Journal of Forest Research 132(2), https://doi.org/10.1007/s10342-012-0670-1 


\title{
Impacts of salvage-logging on the status of deadwood after windthrow in Swiss forests
}

\author{
Kathrin Priewasser • Peter Brang • Hansheinrich Bachofen • \\ Harald Bugmann · Thomas Wohlgemuth
}

Received: 18 April 2012/Revised: 17 October 2012/ Accepted: 9 November 2012/Published online: 22 November 2012

(C) Springer-Verlag Berlin Heidelberg 2012

\begin{abstract}
Downed and standing deadwood (DW) is a key resource for maintaining forest biodiversity. Although extreme events such as windthrow and fires produce large quantities of DW, this substrate is often drastically reduced by logging activities. To elucidate the respecting consequences of salvage-logging, we assessed both quantity and quality of storm-derived DW (storms Vivian 1990 and Lothar 1999) in Swiss forests using a sample of 90 windthrow sites with $\geq 3$ ha complete windthrow and at elevations ranging from 350 to $1,800 \mathrm{~m}$ a.s.l. The majority had been salvage-logged (SL) a few years after the windthrow. On each site, we recorded DW amount and quality on six circular sample plots 20 or $50 \mathrm{~m}^{2}$ in size. DW volume on SL sites was surprisingly high, with $76.4 \mathrm{~m}^{3} \mathrm{ha}^{-1}$ on average 20 years after Vivian and $73.8 \mathrm{~m}^{3} \mathrm{ha}^{-1} 10$ years after Lothar. In comparison, DW volumes on unsalvaged sites, that is, with no post-windthrow intervention (NI), amounted to $270 \mathrm{~m}^{3} \mathrm{ha}^{-1}$. A wide variety of wood decay
\end{abstract}

Communicated by J. Müller.

K. Priewasser $(\bowtie) \cdot$ P. Brang $\cdot$ H. Bachofen · T. Wohlgemuth Swiss Federal Research Institute WSL, Zürcherstrasse 111, 8903 Birmensdorf, Switzerland

e-mail: kathrin.priewasser@wsl.ch

P. Brang

e-mail: peter.brang@wsl.ch

H. Bachofen

e-mail: hansheinrich.bachofen@wsl.ch

T. Wohlgemuth

e-mail: thomas.wohlgemuth@wsl.ch

K. Priewasser · H. Bugmann

Institute of Terrestrial Ecosystems, ETH Zürich,

Universitätsstrasse 16, 8092 Zürich, Switzerland

e-mail: harald.bugmann@env.ethz.ch stages and diameter classes ( 10 to $\geq 70 \mathrm{~cm}$ ) was found on both NI and SL sites, suggesting considerable habitat diversity for DW-associated species irrespective of the treatment. The considerable amounts of DW left after salvage-logging distinctly exceed the minimum DW volumes in forest stands proposed by Müller and Bütler (Eur J For Res 129: 981-992, 2010) in a conservation context, which demonstrates the importance of wind disturbance for biodiversity. Further studies should quantify DW of individual tree species, since habitat requirements are speciesspecific.

Keywords Coarse woody debris $\cdot$ Decay stage $\cdot$ Diameter classes - Wind disturbance

\section{Introduction}

Deadwood (DW) in the form of standing dead trees (snags), logs (downed deadwood), stumps, and buried wood is a natural component of forest ecosystems (Harmon et al. 1986). Decaying wood provides a wide variety of microhabitats and has therefore been proposed as a surrogate for overall species richness (Juutinen et al. 2006), especially in boreal forests (Lassauce et al. 2011). Because species requirements for DW quantity and quality vary considerably (Berg et al. 1994; Schiegg 2001), the availability of downed and standing DW in different stages of decomposition is crucial for species composition and richness (Harmon et al. 1986; Bader et al. 1995). Moreover, DW provides a favourable substrate for tree regeneration (Zielonka 2006b; Baier et al. 2007; Svoboda et al. 2010), particularly in moist mountain forests where luxuriantly growing tall herb communities often impede tree regeneration on open ground (Imbeck and Ott 1987; Wohlgemuth et al. 2002b). 
Given the multiple functions of DW, lack of DW may have disadvantageous effects on soil fertility, forest biodiversity, and forest regeneration. For biodiversity, threshold values for DW of $20 \mathrm{~m}^{3} \mathrm{ha}^{-1}$ have been suggested for European temperate deciduous forests (Kappes et al. 2009), and $33 \mathrm{~m}^{3} \mathrm{ha}^{-1}$ for subalpine Norway spruce (Picea abies L.) forests (Bütler and Schlaepfer 2004). In a careful review of DW thresholds in European forests, Müller and Bütler (2010) proposed similar minimum values, namely $20-30 \mathrm{~m}^{3} \mathrm{ha}^{-1}$ for boreal coniferous forests, $30-50 \mathrm{~m}^{3} \mathrm{ha}^{-1}$ for lowland oak-beech forests, and 20-30 $\mathrm{m}^{3} \mathrm{ha}^{-1}$ for mixed-montane forests.

DW abundance has been investigated in different types of natural and managed forests, as well as on disturbed sites like clear-cuts and burnt sites (Pedlar et al. 2002; Gibb et al. 2005; Eräjää et al. 2010). While many studies have quantified the DW amount and quality on burnt sites and related the results to species richness (e.g. Little et al. 1994; Turner et al. 1997; Tinker and Knight 2000), few have addressed the relationship between DW in windthrow gaps and biodiversity (Bouget and Duelli 2004; Lain et al. 2008). To our knowledge, DW quantity and quality on windthrow areas and clearcuts in Central Europe have not been assessed, even though there is growing awareness of the contribution of natural disturbances (Schelhaas et al. 2003) to the naturalness of forests (Wohlgemuth et al. 2002a).

In the frame of European winter storms, the two most severe events in Switzerland during the last 100 years (Usbeck et al. 2010), namely Vivian (February 1990) and Lothar (December 1999), blew down about 5 million $\mathrm{m}^{3}$ (Schüepp et al. 1994) and 13 million $\mathrm{m}^{3}$ (BUWAL and WSL 2001) of timber, respectively. On most of these windthrow areas, the windthrown or broken timber was salvage-logged ('SL' treatment in this paper), whereas only a few windthrow patches were left unsalvaged with no intervention (i.e. windthrown trees were not removed; 'NI' treatment in this paper). In Switzerland, only rough estimates of post-windthrow DW abundance and quality are available. Those obtained from large-scale forest inventory data ranged from 45 to $90 \mathrm{~m}^{3} \mathrm{ha}^{-1} \mathrm{DW}$ on sample plots either totally or partially damaged by storms (Cioldi et al. 2010). DW in a study in Sweden amounted to $42.3 \mathrm{~m}^{3} \mathrm{ha}^{-1}$ on traditional (control) clear-cuts and $26.0 \mathrm{~m}^{3} \mathrm{ha}^{-1}$ on clear-cuts after additional harvesting of all fuels (Eräjää et al. 2010). These volumes were much greater than expected and imply that windthrow areas in Switzerland that are either salvage-logged or left with no intervention may still have a large DW potential. In addition, even though the general importance of DW for regeneration success in various forests is well known, it has rarely been quantified in Central Europe.

This study therefore aims to (1) quantify DW in windthrow areas with total damage caused by the storms Vivian
(1990) or Lothar (1999), (2) analyse salvage-logging impacts on DW amounts, DW composition (log, stump, and snag volumes), size classes, and decay stages, (3) assess how decay rates vary with elevation (350-1,800 m a.s.1.) 10 years after windthrow, and (4) quantify DW as a substrate for tree regeneration after windthrow.

\section{Materials and methods}

\section{Sample sites}

We used a sample of 90 windthrow areas in Switzerland, in the following called 'sample sites', caused by either the winter storm Vivian, 1990, or Lothar, 1999 (Fig. 1 and Table 1). The sample sites were selected from a database of geospatial information for windthrow patches all over Switzerland, derived from visual interpretations of postdisturbance aerial photographs (Vivian: Federal Office for the Environment FOEN; Lothar: Engineering Consultants H. U. Scherrer) according to two criteria: (1) forest area with full damage and (2) windthrow patch greater than 3 ha. Another criterion was that (3) the type of forest on the site should be one of the four most widespread forest types in Switzerland, that is, beech (Fagus sylvatica L.), silver fir- (Abies alba Mill.) beech, silver fir-Norway spruce, or Norway spruce forest (Wohlgemuth et al. 2008b). Moreover, (4) both SL and NI sites were aimed at being represented evenly. Information about salvage-logging activities was derived from interviews with local foresters. Furthermore, we preferred (5) sample sites with exclusively natural regeneration. The initial number of sample sites was high, but applying these five selection criteria reduced the number considerably. Finally, (6) the sample sites were also selected to geographically represent the spatial distribution of windthrow damage in Switzerland from the Jura Mountains to the Alps. This also ensured that the range of elevation (350-1,800 $\mathrm{m}$ a.s.1.), aspect, and slope $\left(0-52^{\circ}\right)$ was wide. As a result of this selection procedure, 90 sites were left for the data collection, and the final sample consisted of $60 \%$ pure coniferous forest, $24 \%$ deciduous forest, and $16 \%$ mixed coniferous-deciduous forest.

\section{Data collection}

Field work was conducted on 24 Vivian and 66 Lothar sample sites between December 2009 and January 2011. We distinguished between DW as logs (downed DW), stumps (standing DW with height $\leq 1.3 \mathrm{~m}$ ), and snags (standing DW with height $>1.3 \mathrm{~m}$ ). On each sample site, six circular sample plots 20 or $50 \mathrm{~m}^{2}$ in size were defined. Plot sizes of $20 \mathrm{~m}^{2}$ were used for sample sites below 
Fig. 1 Windthrow sample sites in Switzerland: Vivian (1990): empty triangles $=$ salvagelogged, solid triangles $=$ no intervention. Lothar (1999): empty dots = salvage-logged, solid dots $=$ no intervention. Source of map: BFS GEOSTADT/Bundesamt für Landestopografie (Federal Office of Topography) and Swiss Federal Institute for Forest, Snow and Landscape Research WSL

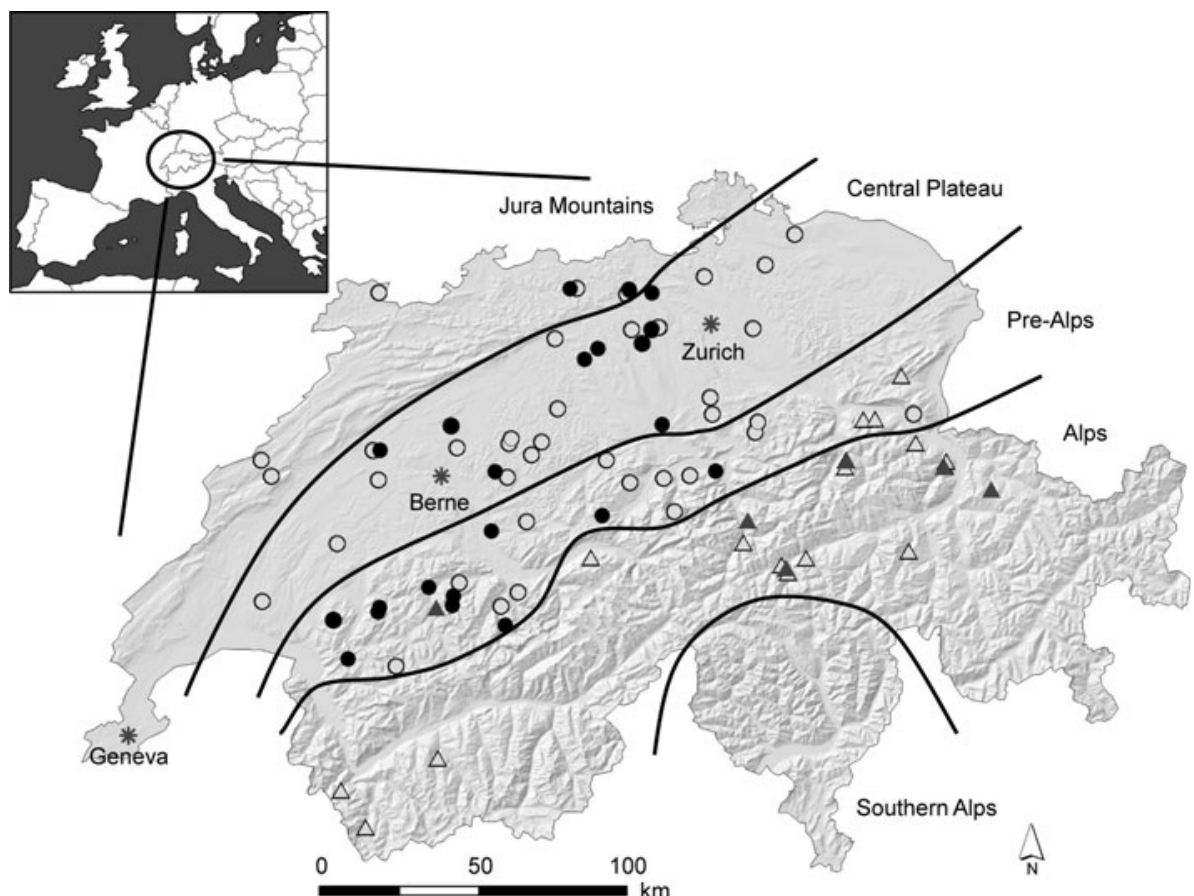

Table 1 Number of sample sites per storm event, treatment and region

\begin{tabular}{lllll}
\hline Region & Vivian & & & Lothar \\
\cline { 2 - 3 } \cline { 5 - 6 } & $\begin{array}{l}\text { Salvage- } \\
\text { logged }\end{array}$ & $\begin{array}{l}\text { No } \\
\text { intervention }\end{array}$ & $\begin{array}{l}\text { Salvage- } \\
\text { logged }\end{array}$ & $\begin{array}{l}\text { No } \\
\text { intervention }\end{array}$ \\
\hline $\begin{array}{l}\text { Jura } \\
\text { mountains }\end{array}$ & 0 & 0 & 5 & 3 \\
$\begin{array}{c}\text { Central } \\
\text { plateau }\end{array}$ & 0 & 0 & 22 & 9 \\
$\begin{array}{l}\text { Pre-Alps } \\
\text { Alps }\end{array}$ & 3 & 1 & 16 & 11 \\
Total & 15 & 5 & 0 & 0 \\
\hline
\end{tabular}

$1,200 \mathrm{~m}$ a.s.l. and of $50 \mathrm{~m}^{2}$ for sites above $1,200 \mathrm{~m}$ a.s.l. to account for presumed higher regeneration densities at lower elevations (Wohlgemuth et al. 2008a) and to optimise time-consuming data collection.

On each sample site, the six circular sample plots were defined along the two axes of an ideal ellipse fitting the windthrow area at distances of 20,40 , and $80 \mathrm{~m}$ from the forest edge (Fig. 2). If a sample site was large enough, one of the two transect lines was placed parallel to the contour line and the second perpendicular to and upslope of the first one. If the sample site shape was unsuitable for applying the distance rule, the two transect lines were slightly shifted. However, the right angle between the two transect lines was always maintained. Transects were rotated clockwise $\left(90^{\circ}, 180^{\circ}\right.$, or $\left.270^{\circ}\right)$ around the centre point if obstacles such as rocks made proper data assessment impossible.

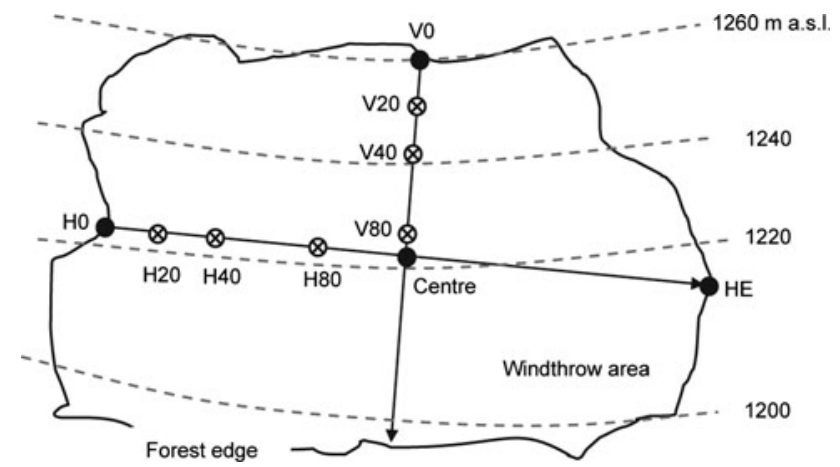

Fig. 2 Sampling design for each windthrow area: Six circular plots were selected on each sample site at the following distances away from two forest edges following the axes of an ellipse fitted to the windthrow patches: $20 \mathrm{~m}$ (H20, V20), $40 \mathrm{~m}$ (H40, V40), and $80 \mathrm{~m}$ (H80, V80), where $\mathrm{H0}, \mathrm{V0}$, and $\mathrm{HE}$ are points along the edge of the forest

On each circular sample plot, all DW pieces with a minimum small-end diameter of $10 \mathrm{~cm}$ and a minimum length of $10 \mathrm{~cm}$ were measured. Diameters at both ends and the length or height of each DW piece were recorded. The parts of DW lying outside of the circular line and buried DW were not measured. For each DW piece, decay was evaluated according to Zielonka's (2006a) eight-stage scale, which considers the shape of DW, the average depth of knife penetration, the presence of branches, and the presence of bark (Table 2). Averaged small- and large-end diameters served for the classification into seven diameter classes ( $\mathrm{I}=10-19 \mathrm{~cm}, \mathrm{II}=20-29 \mathrm{~cm}, \ldots, \mathrm{VII} \geq 70 \mathrm{~cm}$ ). Since identifying the species of DW pieces by visual examination was often ambiguous given the great variety 
Table 2 Eight-degree scale for DW decomposition stage (Zielonka 2006a)

\begin{tabular}{|c|c|c|c|c|}
\hline $\begin{array}{l}\text { Decay } \\
\text { stage }\end{array}$ & Shape & $\begin{array}{l}\text { Average depth of knife } \\
\text { penetration }\end{array}$ & Branches & Bark \\
\hline D1 & Round, smooth & 0-1 mm; hard wood & All branches present & Intact \\
\hline D2 & Round, smooth & $1-5 \mathrm{~mm}$ & $\begin{array}{l}\text { Branches over } 20 \mathrm{~mm} \\
\text { present }\end{array}$ & Partially intact \\
\hline D3 & Round, crevices several mm deep & $5-10 \mathrm{~mm}$ & $\begin{array}{l}\text { Over } 30 \mathrm{~mm} \text { thick } \\
\text { present }\end{array}$ & $\begin{array}{l}\text { Remains on upper } \\
\text { side of } \log \end{array}$ \\
\hline D4 & Round, crevices approx. $5 \mathrm{~mm}$ deep & $10-40 \mathrm{~mm}$ & Only base part present & Usually lacking \\
\hline D5 & Round, crevices approx. $10 \mathrm{~mm}$ deep & $40-60 \mathrm{~mm}$ & $\begin{array}{l}\text { Only thickest base parts } \\
\text { present }\end{array}$ & Mostly lacking \\
\hline D6 & $\begin{array}{l}\text { Slightly flattened, several } \mathrm{cm} \text { thick, pieces tear off } \\
\text { easily }\end{array}$ & $\begin{array}{l}\text { Solid only in central part } \\
\text { of } \log \end{array}$ & $\begin{array}{l}\text { Only thickest base parts } \\
\text { present }\end{array}$ & Completely lacking \\
\hline D7 & $\begin{array}{l}\text { Distinctly flattened, whole log covered with furrows } \\
\text { several } \mathrm{cm} \text { deep }\end{array}$ & Throughout & Completely lacking & Completely lacking \\
\hline D8 & Flattened, covered with vegetation & Throughout & Completely lacking & Completely lacking \\
\hline
\end{tabular}

of forests visited, DW species were not recorded. Prior to the storms Vivian and Lothar, the amount of DW in Swiss forests was generally small. The second Swiss National Inventory (1993-1995; Brassel and Brändli 1999) recorded averages of $6.5 \mathrm{~m}^{3} \mathrm{DW} \mathrm{ha}{ }^{-1}$ in the Jura Mountains, 4.0 in the Central Plateau, and 14.5 in the Northern Pre-Alps. We assume that these DW amounts can be applied not only to the Lothar forests, but also to the situation in forests before Vivian (1990) as the inventory was conducted soon after Vivian. Accordingly, we assumed that most of the DW found in the windthrow sites resulted from the two storms.

In the circular sample plots, saplings taller than $19 \mathrm{~cm}$ that had established after the windthrow were assessed on both DW and forest soil. To distinguish between pre- and post-storm regeneration, we estimated sapling age by counting the whorls on conifers or the tree rings from a stem of a tree outside the circle plot. Alternatively, the tree rings from the oldest branch of a tree inside the circle plot were counted.

\section{Data analysis}

One circular sample plot from one salvage-logged Lothar sample site had to be excluded from all analyses because of one huge standing dead tree that was responsible for the 'NI' aspect of the sample plot in spite of the sample site having been cleared.

The volumes of all DW pieces were calculated with the formula of a truncated circular cone:

$V=\frac{1}{3} \pi h\left(r_{1}^{2}+r_{1} r_{2}+r_{2}^{2}\right)$

where $\mathrm{h}$ is height or length; $r_{1}$, the small-end radius; and $r_{2}$, the large-end radius of the DW piece. To calculate the amount of DW per sample site, measurements of the six circular sample plots were pooled and scaled up to standard values $\left(\mathrm{m}^{3} \mathrm{ha}^{-1}\right)$. Volume, diameter classes, and decay stages of DW were related to treatments (SL vs. NI), windthrow event (20-year-old Vivian and 10-year-old Lothar sites), and elevation. Analyses were performed using a mixed ANOVA design with one between-site factor (treatment) and in some analyses with one within-site factor (type of DW or decay stage). Post hoc pairwise Tukey HSD tests were used to calculate the p-values. Prior to all analyses, response variables were square-root transformed (unless otherwise noted) to meet the assumptions of normality and/or homogeneity of variance. All analyses were performed using the statistical computing system R, version 2.11.1 (R Development Core Team 2011).

\section{Results}

Deadwood volume and structure

Standing and lying DW covered altogether between 0.05 and $21.0 \%$ of the surface on the 90 sample sites. Volumes of DW varied from 1 to $650 \mathrm{~m}^{3} \mathrm{ha}^{-1}$ (Fig. 3), with almost four times more DW on no intervention (NI) sites (average of $270.0 \mathrm{~m}^{3} \mathrm{ha}^{-1}$ ) than on salvage-logged (SL) sites $\left(74.6 \mathrm{~m}^{3} \mathrm{ha}^{-1}\right)$. In detail, DW volumes on SL Vivian and SL Lothar sites were similar: $76.4 \pm 11.6$ (mean \pm SE) and $73.8 \pm 18.1 \mathrm{~m}^{3} \mathrm{ha}^{-1}$, respectively (Table 3 ). The differences in DW volumes between NI Vivian and NI Lothar sample sites were also small: 284.7 and $266.1 \mathrm{~m}^{3}$ $\mathrm{ha}^{-1}$, respectively (Table 3 ). Differences between NI and SL sites were, in contrast, highly significant (ANOVA for Vivian: $F_{1,22}=39.81, P<0.001$; for Lothar: $F_{1,64}=$ 96.8, $P<0.001)$.

On both SL and NI sites, DW consisted predominantly of logs (Fig. 4). The total log volumes on NI sites were five times higher than on SL sites (ANOVA for Vivian: 


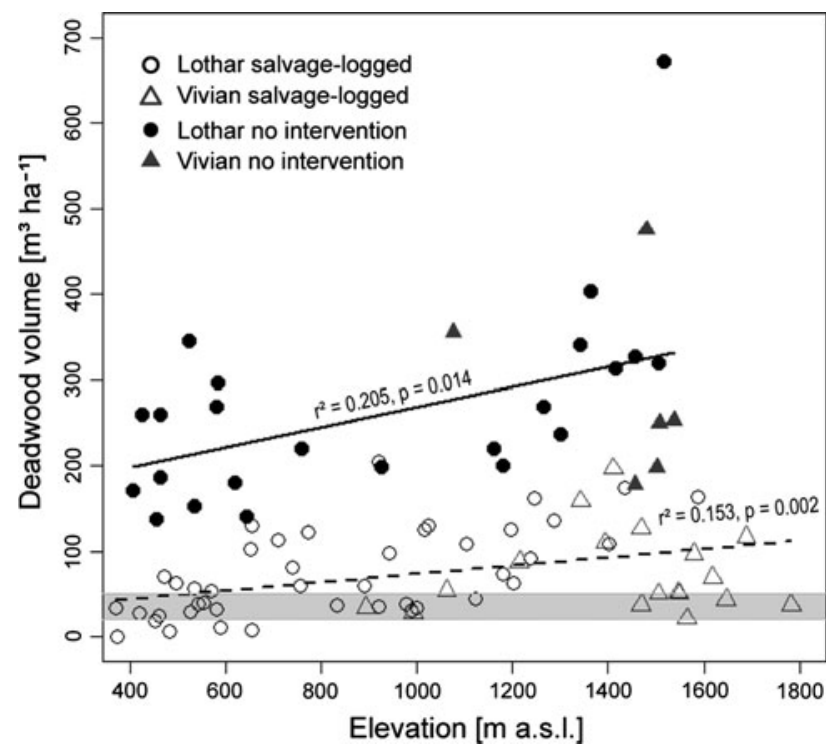

Fig. 3 Deadwood volume and elevation per sample site according to storm event and treatment (salvage-logged, no intervention). Solid line $=$ all sample sites without intervention, dashed line $=$ all salvage-logged sample sites, grey stripe $=$ target deadwood volume range for the three main European forests (lowland oak-beech forests, mixed-montane forests, and boreal coniferous forests)

$F_{1, \quad 22}=21.88, \quad P<0.001 ;$ for Lothar: $F_{1,64}=41.06$, $P<0.001$; Table 3). Stump volumes were higher on SL than on NI sites, but the difference was significant for Lothar sites only. On both NI Vivian and Lothar sites, snag volumes were higher than on SL sites, but for both storm types, the differences were not significant (Table 3). The composition of DW (log, stump, and snag volumes) on SL Vivian and Lothar sites, as well as on NI Vivian and Lothar sites, was similar (Fig. 4), with no significant differences (ANOVA for the interaction between storm and type of DW (log, stump, and snag volumes): for SL sites: $F_{1,59}=0.72, \quad P=0.399$; for NI sites: $F_{1,27}=0.42$, $P=0.522$ ).

Decay stages and size class distribution on Vivian sample sites

The majority of DW on both SL and NI 20-year-old Vivian sites was in decay stages D4-D7 (Fig. 5). These decay stages (D4-D7) accounted for $90 \%$ of the total DW volume on NI sites and for $88 \%$ on SL sample sites. No DW in decay stage D1 was found. The proportion of slightly decayed DW (D2 and D3) was $9 \%$ on both SL and NI sites, whereas that of highly decayed DW (D8) was $1 \%$ on $\mathrm{NI}$ and $3 \%$ on SL sites. DW volumes were greater on NI than on SL sample sites for all decay classes, but the differences were only significant for the decay stages D4, D5, and D6 (ANOVA: $F_{1,22}=43.02, P<0.001$; Table 3).
On NI sites, $97 \%$ of the total DW volume consisted of diameter classes I-V. In contrast, on SL sites, the contribution to these classes was smaller with only $80 \%$ of the total DW volume (Table 3), where DW volume followed approximately a normal distribution. Volumes of DW differed significantly between NI and SL sites in diameter classes II and III only (ANOVA: $F_{1,22}=21.48, P<0.001$; Table 3).

Decay stages and size class distribution on Lothar sample sites

Ten years after the windthrow disturbance, the majority of DW on Lothar sites was in the decay stages D3-D5 (Fig. 6), with $87 \%$ on NI and $73 \%$ on SL sites. As on Vivian sites, no DW in decay stage D1 was found. Early decay stages (D2) were only present in $7 \%$ of the volume of all DW pieces (both NI and SL sites), and advanced decay stages (D6-D8) had a proportion of $6 \%$ on NI sites and $20 \%$ on SL sites. DW volumes were greater on NI than SL sites in decay stages D1-D6 and smaller in decay stages D7 and D8. Only DW volumes from decay stages D3 and D4 differed significantly between SL and NI sample sites (ANOVA: $F_{1,64}=78.91, \quad P<0.001$; Table 3).

NI sites had the same proportion (97\%) of total DW volume in diameter classes I-V as NI Vivian sites, but the proportion on SL Lothar sites (74 \%) was $6 \%$ smaller than on SL Vivian sites $(80 \%)$. On SL Lothar sites, the volume in the seven diameter classes followed, as on SL Vivian sites, approximately, a normal distribution. DW volumes in diameter classes I-V were greater on NI than on SL sites and smaller in diameter classes VI and VII. Only in the three smallest diameter classes (I-III) was DW volume significantly higher on NI than on SL sites (ANOVA: $F_{1,64}=51.03, P<0.001$; Table 3).

Decay rates on Lothar sites along an extended elevational gradient

We expected the decomposition rate to be a function of temperature, that is, decay to decrease with increasing elevation. To test this effect, we selected NI Lothar sample sites $(n=23)$ with a large range of DW pieces in different decay stages (three decay classes: D2-D3, D4-D5, D6D8). Volumes from 13 sites below and 10 sites above 1,000 m a.s.l. were compared. DW volumes above $1,000 \mathrm{~m}$ a.s.l. were significantly higher than those below (ANOVA: $\left.F_{1,21}=7.39, P=0.013\right)$. Decay stage distributions also clearly differed (ANOVA: $F_{2,42}=29.04, P<0.001$ ), and the interaction of decay and elevation showed significant differences (ANOVA: $F_{2,42}=7.65, P=0.001$ ). Above $1,000 \mathrm{~m}$ a.s.l., the average volume of slightly decayed DW 
Table 3 Deadwood volume $\left(\mathrm{m}^{3} \mathrm{ha}^{-1}\right)$ in 2010 resulting from the winter storms Vivian (1990) and Lothar (1999) (mean \pm SE)

\begin{tabular}{|c|c|c|c|c|c|c|}
\hline & \multicolumn{3}{|l|}{ Vivian } & \multicolumn{3}{|l|}{ Lothar } \\
\hline & Salvage-logged & No intervention & $p$ & Salvage-logged & No intervention & $p$ \\
\hline \multicolumn{7}{|l|}{ Type of DW } \\
\hline Snags & $8.0 \pm 2.6$ & $21.3 \pm 13.7$ & 0.890 & $8.0 \pm 2.9$ & $26.1 \pm 11.1$ & 0.199 \\
\hline Stumps & $16.6 \pm 2.9$ & $9.2 \pm 6.1$ & 0.852 & $19.8 \pm 2.5$ & $4.0 \pm 1.3$ & 0.018 \\
\hline Logs & $51.8 \pm 11.1$ & $254.2 \pm 51.3$ & $<0.001$ & $46.0 \pm 7.1$ & $236.0 \pm 18.0$ & $<0.001$ \\
\hline \multicolumn{7}{|l|}{ Decay stages } \\
\hline D2 & $1.1 \pm 1.0$ & $14.4 \pm 12.2$ & 0.927 & $5.2 \pm 2.2$ & $20.7 \pm 6.9$ & 0.264 \\
\hline D3 & $6.1 \pm 2.4$ & $10.1 \pm 3.6$ & 0.999 & $16.3 \pm 3.5$ & $107.2 \pm 20.3$ & $<0.001$ \\
\hline D4 & $13.4 \pm 5.3$ & $51.9 \pm 16.7$ & 0.022 & $23.5 \pm 4.3$ & $85.4 \pm 9.8$ & $<0.001$ \\
\hline D5 & $14.8 \pm 2.6$ & $70.8 \pm 21.4$ & 0.001 & $12.7 \pm 3.0$ & $37.9 \pm 10.4$ & 0.121 \\
\hline D6 & $13.5 \pm 3.1$ & $64.2 \pm 28.5$ & 0.006 & $6.1 \pm 1.7$ & $11.0 \pm 2.7$ & 0.994 \\
\hline D7 & $25.3 \pm 4.4$ & $68.6 \pm 17.7$ & 0.096 & $7.3 \pm 1.4$ & $3.8 \pm 1.3$ & 0.999 \\
\hline D8 & $2.2 \pm 1.3$ & $4.7 \pm 2.7$ & 1.000 & $2.7 \pm 1.6$ & $0.2 \pm 0.1$ & 1.000 \\
\hline \multicolumn{7}{|l|}{ Diameter classes } \\
\hline I $(10-19 \mathrm{~cm})$ & $2.8 \pm 1.0$ & $18.5 \pm 9.5$ & 0.804 & $6.0 \pm 0.9$ & $29.1 \pm 3.8$ & $<0.001$ \\
\hline II $(20-29 \mathrm{~cm})$ & $7.9 \pm 1.3$ & $90.7 \pm 22.0$ & $<0.001$ & $8.8 \pm 1.5$ & $79.0 \pm 10.1$ & $<0.001$ \\
\hline III $(30-39 \mathrm{~cm})$ & $18.1 \pm 5.0$ & $86.3 \pm 11.7$ & $<0.001$ & $11.6 \pm 2.5$ & $93.1 \pm 10.6$ & $<0.001$ \\
\hline IV $(40-49 \mathrm{~cm})$ & $18.1 \pm 3.6$ & $49.2 \pm 34.1$ & 0.977 & $16.4 \pm 3.2$ & $33.5 \pm 7.4$ & 0.699 \\
\hline $\mathrm{V}(50-59 \mathrm{~cm})$ & $14.0 \pm 3.1$ & $31.4 \pm 14.7$ & 0.999 & $11.8 \pm 2.8$ & $23.3 \pm 8.5$ & 0.996 \\
\hline $\mathrm{VI}(60-69 \mathrm{~cm})$ & $9.2 \pm 3.1$ & $6.3 \pm 4.5$ & 0.999 & $8.5 \pm 2.5$ & $4.4 \pm 2.0$ & 0.998 \\
\hline VII $(>70 \mathrm{~cm})$ & $6.4 \pm 2.3$ & $2.3 \pm 2.3$ & 0.999 & $10.8 \pm 3.0$ & $3.8 \pm 3.8$ & 0.713 \\
\hline Total & $76.4 \pm 11.6$ & $284.7 \pm 45.5$ & $<0.001$ & $73.8 \pm 18.1$ & $266.1 \pm 9.1$ & $<0.001$ \\
\hline
\end{tabular}

Decay stage D1 is missing because no new DW was found. Differences between treatments are based on a post hoc pairwise Tukey HSD test Significant values are in bold

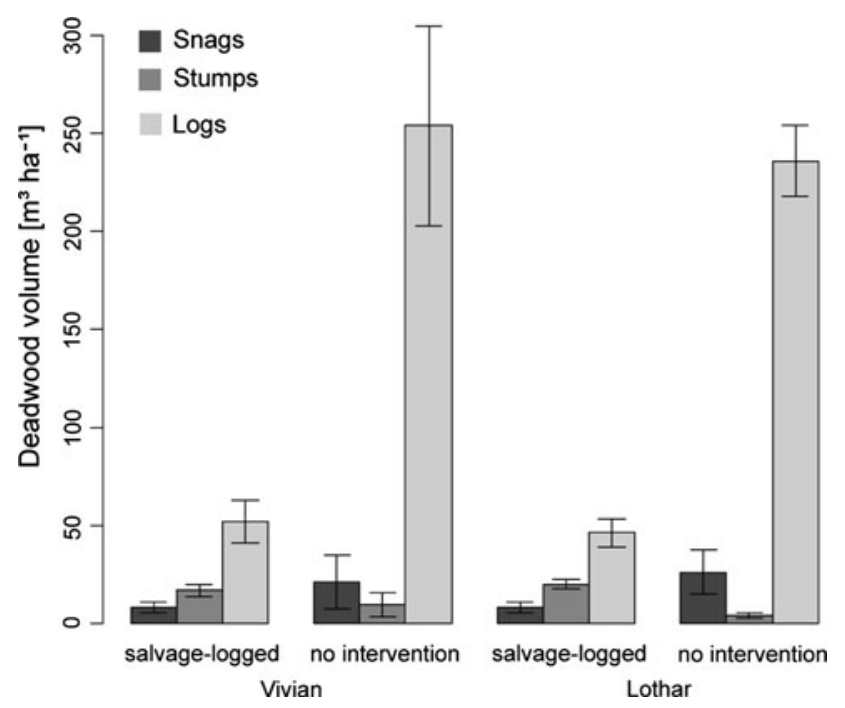

Fig. 4 Snag, stump, and log volumes on salvage-logged and no intervention Vivian (1990) and Lothar (1999) sample sites

(D2 and D3) was significantly higher than below 1,000 m a.s.1. (Tukey's HSD: $P<0.001$; Fig. 7). In contrast, volumes of moderately decayed DW (D4 and D5) were smaller on sites above $1,000 \mathrm{~m}$ than on sites below 1,000 $\mathrm{m}$ a.s.l., although volumes did not differ significantly

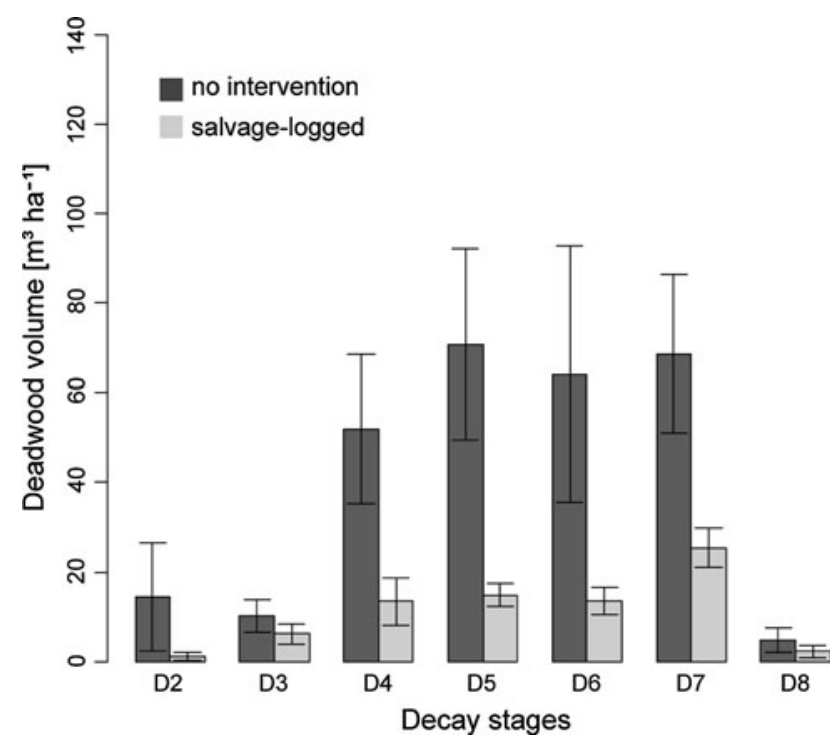

Fig. 5 Deadwood volume per decay stage on Vivian (1990) sample sites. For abbreviations, see Table 2

(Tukey's HSD: $P=0.895$ ). DW volumes in advanced decay stages (D6-D8) were similar below and above $1,000 \mathrm{~m}$ a.s.1. The highest volumes of moderately decayed DW occurred below 1,000 m a.s.1., in contrast to slightly 


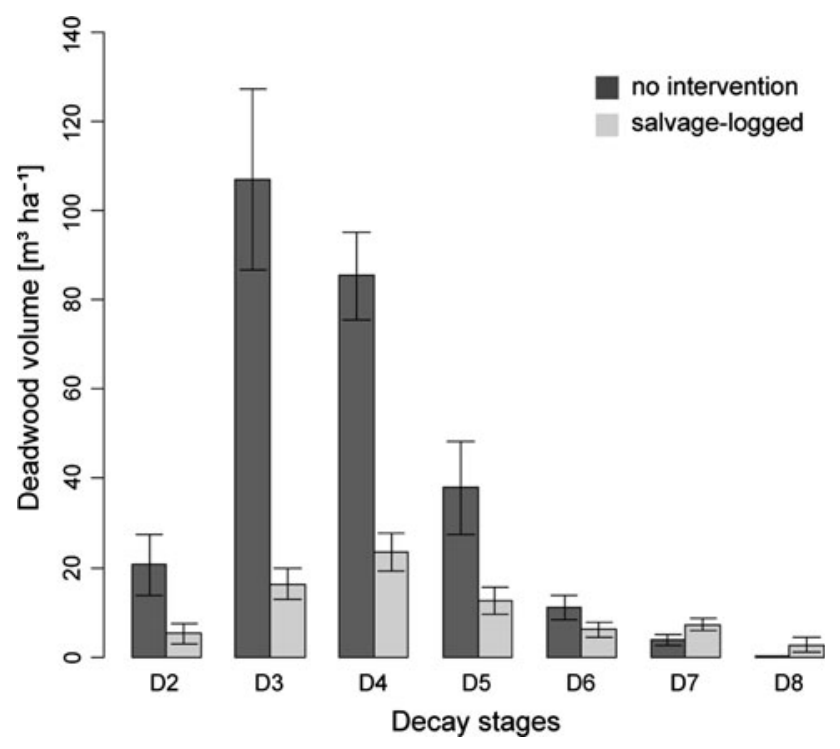

Fig. 6 Deadwood volume per decay stage on Lothar (1999) sample sites. For abbreviations, see Table 2

decayed DW, which was most prominent above 1,000 m a.s.l. (significant at the $10 \%$ level; Tukey's HSD: $P=0.062$ and $P=0.060$, respectively; Fig. 7).

Tree regeneration on deadwood

On the 20-year-old Vivian sample sites $(n=24)$, a total of 81 saplings $\geq 20 \mathrm{~cm}$ were found on DW substrate. In contrast, 62 saplings were found on the 10-year-old Lothar sample sites $(n=66)$. On $83 \%(n=20)$ of all Vivian sites, saplings were present on DW, but regeneration on
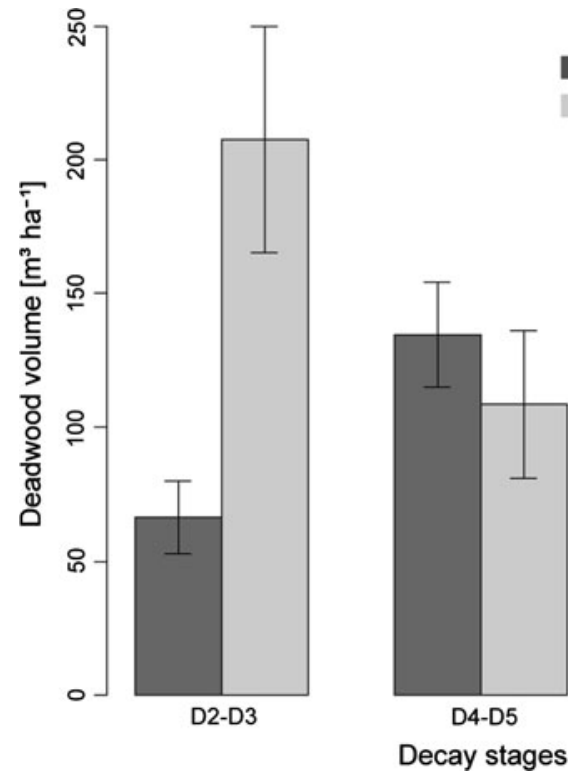

below $1000 \mathrm{~m}$ a.s.I. above $1000 \mathrm{~m}$ a.s.l.

Fig. 7 Volumes of deadwood per elevation zone and of slightly decayed (D2-D3), moderately decayed (D4-D5), and well-decayed deadwood (D6-D8) on no intervention Lothar (1999) sample sites this substrate was restricted to only $32 \%(n=21)$ of the younger Lothar sites. Since saplings on DW were absent on the majority of the Lothar sites $(n=45)$, only Vivian sites were considered for further analysis.

For each Vivian site, sapling numbers were transformed to densities per square meter of substrate, distinguishing 'deadwood', and 'forest soil'. Sapling density did not vary significantly between deadwood $\left(0.50 \pm 0.15 \mathrm{~m}^{-2}\right)$ and forest soil $\left(0.42 \pm 0.07 \mathrm{~m}^{-2}\right.$; ANOVA: $F_{1,23}=0.47$, $P=0.496)$. However, the 81 saplings found on deadwood are very few compared to 2,920 saplings counted on forest soil. Two-thirds $(66.7 \%)$ of all saplings found on deadwood were Norway spruce, $8.6 \%$ European larch (Larix decidua Mill.), $7.4 \%$ rowan (Sorbus aucuparia L.), and $17.3 \%$ individuals belonging to other tree species. On forest soil, the proportions were $35.6 \%$ Norway spruce; $15.3 \%$, sycamore (Acer pseudoplatanus L.); $9.9 \%$, rowan; $7.1 \%$, European larch; $5.8 \%$, red elder (Sambucus racemosa L.); and $26.3 \%$, other woody species. Average sapling height on deadwood was $63.8 \pm 12.6 \mathrm{~cm}$, which is clearly and significantly smaller than on forest soil, where saplings grew to $143.7 \pm 8.2 \mathrm{~cm}$ (no square-root transformation, ANOVA: $\left.F_{1,23}=29.91, P<0.001\right)$.

\section{Discussion}

Our study revealed surprisingly high DW volumes $\left(74.6 \mathrm{~m}^{3}\right.$ $\mathrm{ha}^{-1}$ ) on salvage-logged windthrow areas in Switzerland. Since buried DW was not measured, total DW volumes are likely to be even larger. A comparison with DW amounts from other windthrow areas worldwide is not possible due to the lack of comparable studies. However, our measured values exceed post-clear-cut DW volumes in Canada and Scandinavia by factors as high as 2.3 (Sturtevant et al. 1997; Eräjää et al. 2010) and 5.5 (Gibb et al. 2005). These distinct differences may have several explanations. One reason may be that the growing stock in boreal forests today (MCPFE 2007) is small, with averages of $98 \mathrm{~m}^{3} \mathrm{ha}^{-1}$ in Finland, $111 \mathrm{~m}^{3} \mathrm{ha}^{-1}$ in Sweden, or $201 \mathrm{~m}^{3} \mathrm{ha}^{-1}$ in Estonia. In comparison, growing stocks in Swiss forests (dimensions from the pole stage upward, i.e. DBH $>12 \mathrm{~cm}$ ) amount to $374 \mathrm{~m}^{3} \mathrm{ha}^{-1}$ (Cioldi et al. 2010). Another explanation of the big differences may be that calculations of DW volumes are strongly affected by the measurement method used, and comparisons of DW volumes calculated by different researchers must thus be treated with caution (Eräjää et al. 2010). Adapting the criteria in Gibb et al. (2005) to our sample sites, the estimates of DW volumes for SL windthrow areas diminish to $50.2 \mathrm{~m}^{3} \mathrm{ha}^{-1}$ (Vivian) and to $49.9 \mathrm{~m}^{3} \mathrm{ha}^{-1}$ (Lothar). The resulting amounts are, nevertheless, still clearly higher than those measured by Gibb et al. (2005). Importantly, the DW volumes found in SL windthrow areas 
are twice as large as the target DW ranges proposed by Müller and Bütler (2010) in a biodiversity conservation context.

The average DW volume on unsalvaged sites, that is, with no post-windthrow intervention (NI), was surprisingly low $\left(270.0 \mathrm{~m}^{3} \mathrm{ha}^{-1}\right)$ compared to the growing stock in Swiss forests, which, on average, ranges from $327 \mathrm{~m}^{3} \mathrm{ha}^{-1}$ in the Alps to $475 \mathrm{~m}^{3} \mathrm{ha}^{-1}$ in the Pre-Alps (Cioldi et al. 2010). We assume that, among the 29 NI sites found, stands with a low growing stock were overrepresented because windthrown stands with a high growing stock had mostly been harvested, that is, a presumed reason for no intervention was actually a low growing stock.

On all sites, logs accounted for the great majority of DW, although the log volume on SL sites was much smaller than on NI sites. The volume of stumps and snags was similar on SL and NI sites, but on NI Lothar sites, stump volume was smaller than on SL Lothar sites, probably due to the fact that harvesting leaves stumps. Not only was the DW variation similar on SL and NI sites, but also was the diameter class distribution of DW volumes. On all NI windthrow sites, DW volumes in diameter classes $<50 \mathrm{~cm}$ dominated. We presume that those windthrow areas stocked with small diameter trees were more likely to have had no intervention than the ones stocked with thicker trees, as can be seen in Fig. 3, where only six of the 29 NI sites had DW volumes exceeding the level of average growing stock for forests in the Alps, that is, $327 \mathrm{~m}^{3} \mathrm{ha}^{-1}$ (Cioldi et al. 2010). In Switzerland, however, two-thirds of the total volume of living trees are comprised of trees with a DBH between 12 and $51 \mathrm{~cm}$. ${ }^{1}$ On both SL Vivian and SL Lothar sites, the highest DW volumes were found in diameter classes III-V $(30-59 \mathrm{~cm})$, while clear-cuts in Canada and Scandinavia had the highest DW volumes or number of DW pieces in diameter classes $<20 \mathrm{~cm}$ (Pedlar et al. 2002; Gibb et al. 2005; Moroni and Ryan 2010). The range of DW diameter classes in our study was largely irrespective of the post-windthrow management.

The decay stages of DW depend on the time since tree death (Zielonka 2006a), which in our study directly translates into the time since disturbance. Since we only assessed windthrow areas with total damage, we found no recent DW (D1) on Vivian and Lothar sites, that is, no new DW had accumulated since the storms. Not surprisingly, DW on 20-year-old Vivian sites (1990) was in a more advanced stage of decay than DW on 10-year-old Lothar sites (1999). Pre-storm DW volumes were assumed to be in decay stages D8 on the Vivian and D7/D8 on the Lothar sample sites and were generally small (Figs. 5, 6). In

\footnotetext{
${ }^{1}$ http://www .1 fi.ch/resultate/resultate.php?zigrNr=21\&befundNr= $1029 \&$ inv $\mathrm{Nr}=350 \&$ ausw $\mathrm{Nr}=434 \& \mathrm{p}=$ crit $\&$ ind $\mathrm{Nr}=102 \&$ frmFnc $=$ Resultate+anzeigen \&itNr=15237, 08.11.2011.
}

contrast to untouched old-growth forests (Sippola et al. 1998; Zielonka 2006a), the simultaneous presence of all decay stages is merely a transient phenomenon in a postwindthrow area with total damage. In such areas, it is likely that locally, there will be a lack of less decayed DW, but a supply of highly decayed DW in the medium and long-term until new disturbances produce new DW. In the long-term, the composition of DW in areas with total windthrow damage will develop differently from that in untouched old-growth forests with a small-scale disturbance regime, where repeated but episodic disturbances eventually result in the co-occurrence of all DW decay stages (Spies et al. 1988; Mountford 2002; Christensen et al. 2005).

Regarding DW structure (DW type, diameter class, and decay stage), SL windthrow areas are not less diverse than NI windthrow areas. Hence, they provide as many habitats for different DW-associated species requiring particular DW structures as NI areas. Since many DW dwellers depend not only on particular DW structures (Berg et al. 1994; Bader et al. 1995; Schiegg 2001), but also on particular DW tree species (Jonsell et al. 2004; Lohmus et al. 2010), further studies should focus on the tree species composition of DW and the specific decay time involved with respect to disturbance regimes.

In the 10-year-old Lothar sites, volumes of slightly decayed DW peaked above 1,000 m a.s.l., and volumes of moderately decayed DW below $1,000 \mathrm{~m}$ a.s.l. This suggests slower decay rates with increasing elevation, which is in line with Kueppers et al.'s (2004) finding that the turnover time of lodgepole pine DW on cool sites was twice that on a site where air temperature was $2.5-3{ }^{\circ} \mathrm{C}$ higher. Mackensen et al. (2003) also found that the mean annual temperature strongly correlated with the DW decay rate. However, DW decay rates also depend on other factors, such as how long the wood has been in contact with the ground (Zielonka 2006a) or the tree species. The windthrow sites we sampled at higher elevations had, on average, higher DW volumes than sites at lower elevations (Fig. 3). This is partly due to the fact that harvesting at higher elevations is less cost-efficient because slopes are generally steeper and less accessible than in the lowlands.

After 30 years, DW turns into an appropriate seedbed, but the first seedlings may already establish during the second decade after tree death (Zielonka 2006b). Since our assessment was only 20 years after Vivian and only tree individuals taller than $19 \mathrm{~cm}$ were measured, we suspect that part of the DW-borne regeneration established on DW pieces older than 20 years. However, the sapling density of $0.5 \mathrm{~m}^{-2}$ on DW substrate was roughly similar to that found on forest soil, where the great majority of regenerating trees had already grown taller than the saplings on DW. Deadwood as substrate may be crucial for regeneration in moist spruce forests, as found by Imbeck and Ott (1987) in 
Swiss mountain forests and Svoboda et al. (2010) in the Bohemian forest, Czech Republic. Given the presence of advanced decayed DW on Vivian windthrow sites, this substrate seems to have been as important for tree recruitment as forest soil. Further, the availability of DW is also important for the heterogeneous establishment of tree seedlings during the succession process, since it provides a delayed seedbed for tree regeneration (Zielonka 2006b) and, consequently, leads to a more complex and unevenaged forest in the long-term (Donato et al. 2012).

Our findings indicate that wind disturbances are important for DW accumulation, independent of the poststorm management and that current practices of salvagelogging on windthrow areas are likely to leave enough DW to ensure a wide diversity of habitats for DW dwellers. While we are confident that our results are highly representative for the climatically and edaphically diverse forests of Switzerland, we are cautious regarding their implications for other regions and larger scales. We found, however, similar DW conditions in the windthrow areas produced by the two winter storms Vivian (1990) and Lothar (1999). Specifically, the total DW amount, the DW volume variation across the three DW types (logs, stumps, and snags), and the diameter class distribution were similar on Vivian and Lothar sites even though the two storms happened at different times and affected different regions (Usbeck et al. 2010). Questions still remain about whether the wide range of logging practices in Switzerland (especially the variations between lowland and mountain forestry) are similar to logging practices in other countries in Central Europe. Further studies with more detailed information about DW tree species are needed to determine whether forests in other countries affected by windthrow also exhibit the same post-disturbance deadwood patterns, which would enable generalizations for forests in Central and Western Europe, where European winter storms are most frequent.

Acknowledgments We thank the Federal Office for the Environment FOEN (Bundesamt für Umwelt BAFU) for financial support, Barbara Moser for statistical advice, Silvia Dingwall for the linguistic revision of the manuscript and two anonymous reviewers for their valuable comments and suggestions.

\section{References}

Bader P, Jansson S, Jonsson BG (1995) Wood-inhabiting fungi and substratum decline in selectively logged boreal spruce forests. Biol Conserv 72:355-362

Baier R, Meyer J, Göttlein A (2007) Regeneration niches of Norway spruce (Picea abies [L.] Karst.) saplings in small canopy gaps in mixed mountain forests of the Bavarian Limestone Alps. Eur J For Res 126:11-22

Berg A, Ehnström B, Gustafsson L, Hallingbäck T, Jonsell M, Weslien J (1994) Threatened plant, animal, and fungus species in
Swedish forests-distribution and habitat associations. Conserv Biol 8:718-731

Bouget C, Duelli P (2004) The effects of windthrow on forest insect communities: a literature review. Biol Conserv 118:281-299

Brassel P, Brändli UB (1999) Schweizerisches Landesforstinventar: Ergebnisse der Zweitaufnahme 1993 - 1995. Eidgenössische Forschungsanstalt für Wald, Schnee und Landschaft, WSL, Birmensdorf. Bundesamt für Umwelt, Wald und Landschaft, BUWAL, Bern

Bütler R, Schlaepfer R (2004) Wie viel Totholz braucht der Wald? Schweiz Z Forstwes 150:31-37

BUWAL, WSL (2001) Lothar. Der Orkan 1999. Ereignisanalyse. Eidgenössische Forschungsanstalt für Wald, Schnee und Landschaft, Birmensdorf. Bundesamt für Umwelt, Wald und Landschaft, BUWAL, Bern

Christensen M, Hahn K, Mountford EP, Ódor P, Standovár T, Rozenbergar D, Diaci J, Wijdeven S, Meyer P, Winter S, Vrska $\mathrm{T}$ (2005) Dead wood in European beech (Fagus sylvatica) forest reserves. Forest Ecol Manag 210:267-282

Cioldi F, Baltensweiler A, Brändli U-B, Duc P, Ginzler C, Bonardi AH, Thürig E, Ulmer U (2010) Waldressourcen. In: Brändli U-B (ed) Schweizerisches Landesforstinventar Ergebnisse der dritten Erhebung 2004-2006. Eidgenössische Forschungsanstalt für Wald, Schnee und Landschaft WSL, Birmensdorf. Bundesamt für Umwelt BAFU, Bern, pp 31-114

Donato DC, Campbell JL, Franklin JF (2012) Multiple successional pathways and precocity in forest development: can some forests be born complex? J Veg Sci 23:576-584

Eräjää S, Halme P, Kotiaho JS, Markkanen A, Toivanen T (2010) The volume and composition of dead wood on traditional and forest fuel harvested clear-cuts. Silva Fenn 44:203-211

Gibb H, Ball JP, Johansson T, Atlegrim O, Hjältén J, Danell K (2005) Effects of management on coarse woody debris volume and composition in boreal forests in northern Sweden. Scand J Forest Res 20:213-222

Harmon ME, Franklin JF, Swanson FJ, Sollins P, Gregory SV, Lattin JD, Anderson NH, Cline SP, Aumen NG, Sedell JR, Lienkaemper GW, Cromack K, Cummins KW (1986) Ecology of coarse woody debris in temperate ecosystems. Adv Ecol Res 15:133-302

Imbeck H, Ott E (1987) Verjüngungsökologische Untersuchungen in einem hochstaudenreichen subalpinen Fichtenwald, mit spezieller Berücksichtigung der Schneeablagerung und der Lawinenbildung. Eidgenösschische Forschungsanstalt für Wald, Schnee und Landschaft WSL, Birmensdorf

Jonsell M, Nitterus K, Stighall K (2004) Saproxylic beetles in natural and man-made deciduous high stumps retained for conservation. Biol Conserv 118:163-173

Juutinen A, Monkkonen M, Sippola AL (2006) Cost-efficiency of decaying wood as a surrogate for overall species richness in boreal forests. Conserv Biol 20:74-84

Kappes H, Jabin M, Kulfan J, Zach P, Topp W (2009) Spatial patterns of litter-dwelling taxa in relation to the amounts of coarse woody debris in European temperate deciduous forests. Forest Ecol Manag 257:1255-1260

Kueppers LM, Southon J, Baer P, Harte J (2004) Dead wood biomass and turnover time, measured by radiocarbon, along a subalpine elevation gradient. Oecologia 141:641-651

Lain EJ, Haney A, Burris JM, Burton J (2008) Response of vegetation and birds to severe wind disturbance and salvage logging in a southern boreal forest. Forest Ecol Manag 256:863-871

Lassauce A, Paillet Y, Jactel H, Bouget C (2011) Deadwood as a surrogate for forest biodiversity: meta-analysis of correlations between deadwood volume and species richness of saproxylic organisms. Ecol Indic 11:1027-1039

Little RL, Peterson DL, Conquest LL (1994) Regeneration of subalpine fir (Abies lasiocarpa) following fire-effects of climate and other factors. Can J For Res-Rev Can Rech For 24:934-944 
Lohmus A, Kinks M, Soon M (2010) The importance of dead-wood supply for woodpeckers in Estonia. Baltic For 16:76-86

Mackensen J, Bauhus J, Webber E (2003) Decomposition rates of coarse woody debris-A review with particular emphasis on Australian tree species. Aust J Bot 51:27-37

MCPFE (2007) State of Europe's forests 2007. The MCPFE report on sustainable forest management in Europe. In: MCPFE, UNECO, FAO (Eds.), Warsaw, p 263

Moroni MT, Ryan DAJ (2010) Deadwood abundance in recently harvested and old Nova Scotia hardwood forests. Forestry 83:219-227

Mountford EP (2002) Fallen dead wood levels in the near-natural beech forest at La Tillaie reserve, Fontainebleau, France. Forestry 75:203-208

Müller J, Bütler R (2010) A review of habitat thresholds for dead wood: a baseline for management recommendations in European forests. Eur J For Res 129:981-992

Pedlar JH, Pearce JL, Venier LA, McKenney DW (2002) Coarse woody debris in relation to disturbance and forest type in boreal Canada. Forest Ecol Manag 158:189-194

R Development Core Team (2011) R: a language and environment for statistical computing. R Foundation for Statistical Computing, Vienna

Schelhaas MJ, Nabuurs GJ, Schuck A (2003) Natural disturbances in the European forests in the 19th and 20th centuries. Glob Change Biol 9:1620-1633

Schiegg K (2001) Saproxylic insect diversity of beech: limbs are richer than trunks. Forest Ecol Manag 149:295-304

Schüepp M, Schiesser HH, Huntrieser H, Scherrer HU, Schmidtke H (1994) The winterstorm Vivian of 27 February 1990 - about the meteorological development, wind forces and damage situation in the forests of Switzerland. Theor Appl Climatol 49:183-200

Sippola AL, Siitonen J, Kallio R (1998) Amount and quality of coarse woody debris in natural and managed coniferous forests near the timberline in Finnish Lapland. Scand J Forest Res 13:204-214

Spies TA, Franklin JF, Thomas TB (1988) Coarse woody debris in douglas-fir forests of western Oregon and Washington. Ecology 69:1689-1702
Sturtevant BR, Bissonette JA, Long JN, Roberts DW (1997) Coarse woody debris as a function of age, stand structure, and disturbance in boreal Newfoundland. Ecol Appl 7:702-712

Svoboda M, Fraver S, Janda P, Bace R, Zenáhlíková J (2010) Natural development and regeneration of a Central European montane spruce forest. Forest Ecol Manag 260:707-714

Tinker DB, Knight DH (2000) Coarse woody debris following fire and logging in Wyoming lodgepole pine forests. Ecosystems 3:472-483

Turner MG, Romme WH, Gardner RH, Hargrove WW (1997) Effects of fire size and pattern on early succession in Yellowstone National Park. Ecol Monogr 67:411-433

Usbeck T, Wohlgemuth T, Dobbertin M, Pfister C, Bürgi A, Rebetez M (2010) Increasing storm damage to forests in Switzerland from 1858 to 2007. Agric For Meteorol 150:47-55

Wohlgemuth T, Bürgi M, Scheidegger C, Schütz M (2002a) Dominance reduction of species through disturbance-a proposed management principle for central European forests. Forest Ecol Manag 166:1-15

Wohlgemuth T, Kull P, Wüthrich H (2002b) Disturbance of microsites and early tree regeneration after windthrow in Swiss mountain forests due to the winter storm Vivian 1990. For Snow Landsc Res 77:17-47

Wohlgemuth T, Conedera M, Kupferschmid A, Moser B, Usbeck T, Brang P, Dobbertin M (2008a) Effekte des Klimawandels auf Windwurf, Waldbrand und Walddynamik im Schweizer Wald. Schweiz Z Forstwes 159:326-334

Wohlgemuth T, Moser B, Brändli UB, Kull P, Schütz M (2008b) Diversity of forest plant species at the community and landscape scales in Switzerland. Plant Biosyst 142:604-613

Zielonka T (2006a) Quantity and decay stages of coarse woody debris in old-growth subalpine spruce forests of the western Carpathians, Poland. Can J For Res-Rev Can Rech For 36:2614-2622

Zielonka T (2006b) When does dead wood turn into a substrate for spruce replacement? J Veg Sci 17:739-746 